\title{
Preoperative workup to assess indication for laparoscopic treatment in gastroesophageal reflux disease
}

\author{
S. Pérez-Holanda, G. L. Urdiales, J. A. Fernández, L. España, J. Rodríguez-Rubio, M. D. Martínez, \\ F. Fernández, S. Tojo, P. Fernández-Muñiz, M. Calleja and D. Valverde \\ Department of General Surgery. Valle del Nalón Hospital. Langreo, Asturias, Spain
}

\section{RESUMEN}

Introducción y objetivos: la cirugía antirreflujo realizada por un cirujano experto es una opción para el tratamiento de mantenimiento para el paciente con enfermedad por reflujo gastroesofágico (ERGE) bien documentada. La "buena documentación" de la ERGE es difícil de llevar a cabo, dado que se trata de una entidad multifactorial, en la que la unión gastroesofágica, con sus condiciones tan especiales tanto anatómicas como funcionales, es determinante. Para evaluar preoperatoriamente tanto el diagnóstico como la indicación quirúrgica de los pacientes que han sido intervenidos mediante un procedimiento laparoscópico antirreflujo en nuestro centro, hemos estudiado retrospectivamente sus historiales clínicos.

Métodos: se analizaron retrospectivamente los historiales clínicos de los pacientes de nuestra Área Sanitaria sometidos a un procedimiento laparoscópico antirreflujo desde diciembre de 1997 hasta febrero de 2007. Para evaluar el aseguramiento preoperatorio en el diagnóstico y la indicación quirúrgica, se tomaron los datos epidemiológicos, la sintomatología, las pruebas diagnósticas realizadas, tanto morfológicas como funcionales, la terapéutica médica pautada y la indicación quirúrgica recogida en la historia clínica de cada uno de los pacientes. La información obtenida fue analizada estadísticamente mediante los test bivariantes. Las diferencias obtenidas fueron significativas cuando el valor de p resultó igual o menor a 0,05.

Resultados: se estudiaron 100 pacientes $(50 \%$ mujeres, con una edad media de 51,31 \pm 13,53 años) intervenidos mediante cirugía antirreflujo por vía laparoscópica. Su sintomatología previa duró 56,47 $\pm 61,33$ meses. El 95\% de los pacientes presentó una anormalidad anatómica. La monitorización del pH diagnosticó a 3 cuartas partes de ellos. Y la indicación quirúrgica más frecuente resultó la recurrencia o persistencia de la esofagitis a pesar de un adecuado tratamiento médico (52 casos).

Conclusiones: según los datos recogidos retrospectivamente en sus historiales clínicos, nuestros pacientes tuvieron un diagnóstico preoperatorio bien documentado (incluyendo tanto el reflujo no erosivo como el erosivo) en el $100 \%$ de los casos y una indicación quirúrgica sólidamente fundamentada en el 94\% de ellos.

\begin{abstract}
Introduction and objectives: antireflux surgery performed by an experienced surgeon is a maintenance option for patients with well-documented gastroesophageal reflux disease (GERD). Well-documented GERD is difficult to find, as GERD is a multifactorial disease in which the gastroesophageal junction, with its special anatomical and functional components, is important. In order to examine patient preoperative workups, and their indication for surgical treatment in GERD, we retrospectively studied patients who underwent a laparoscopic antireflux procedure.

Methods: preoperative workups in patients from our health care area who underwent a laparoscopic antireflux procedure from December 1997 to February 2007 were retrospectively analyzed. Data related to epidemiological findings, symptoms, morphologic and functional evaluation, medical therapy, and indication for surgical treatment were recorded and statistically analyzed by means of a bivariate test. Differences were significant when the $\mathrm{p}$ value was equal to or less than 0.05 .

Results: 100 patients ( $50 \%$ female, $51.31 \pm 13.53$ years of age) underwent a laparoscopic antireflux surgery after $56.47 \pm$ 61.33 months with symptoms. Ninety-five percent of patients had an anatomical abnormality. The $\mathrm{pH}$ monitoring test diagnosed three quarters of cases. The most frequent indication for GERD treatment was persistent or recurrent esophagitis despite adequate medical treatment (52 cases).

Conclusions: based on our preoperative workup, as described, 100 percent of subjects were well documented and diagnosed with GERD (both non-erosive reflux disease and erosive reflux disease), and their indication for laparoscopic treatment was retrospectively assessed in $94 \%$ of cases.
\end{abstract}


Palabras clave: Bomba de protones. Desórdenes en la deglución. Esofagitis. Funduplicatura. Reflujo gastroesofágico. Omeprazol.
Key words: Deglutition disorders. Esophagitis. Fundoplication. Gastroesophageal reflux. Omeprazole. Proton pump.

Pérez-Holanda S, Urdiales GL, Fernández JA, España L, Rodríguez-Rubio J, Martínez MD, Fernández F, Tojo S, Fernández-Muñiz P, Calleja M, Valverde D. Preoperative workup to assess indication for laparoscopic treatment in gastroesophageal reflux disease. Rev Esp Enferm Dig 2008; 100: 405-410.

\section{INTRODUCTION}

Today, gastroesophageal reflux disease (GERD) is defined as the presence of a risk for organic complications by increased gastroesophageal reflux and/or a significant limitation of health-related well-being such as quality of life due to reflux symptoms (1). Data from literature indicate that up to $44 \%$ of the adult population describe symptoms characteristic of GERD, and 10-50\% will need long-term treatment of some kind for them (2). Recently, Ponce and the Iberge Study Group (3) have reported a prevalence of GERD among adults of $15 \%$ in Spain, which merely showed some detriment from $32 \%$ reported previously (4).

Guidelines for the diagnosis and treatment of GERD were updated by the American College of Gastroenterology in 2005 (5). In them, antireflux surgery performed by an experienced surgeon is a maintenance option for the patient with well-documented GERD (level of evidence II).

Well-documented GERD is difficult to carry out, based on GERD is a multifactorial determined disease in which the gastroesophageal junction with its special anatomical and functional components is important (1).

In order to examine both patients' preoperative workup, and their indication for surgical treatment in GERD, we retrospectively studied patients who underwent a laparoscopic antireflux procedure.

\section{MATERIALS AND METHODS}

This study was designed as a single-center, clinical, descriptive, and retrospective trial. The sample was taken from the Department of General Surgery of the Valle del Nalón Hospital from December 1997 to February 2007. Our hospital provides surgical services to a health care area in Asturias (Northern Spain), classified as a rural environment, and according to every places of residence has fewer than 15,000 inhabitants. The census was 65,033 inhabitants, being evaluated based on the most recent available data (Review of Census, INE, 2001).
Patients to be included in this study were evaluated according to the following inclusion and exclusion criteria:

- Inclusion criteria were: Age $>18$ years, well-documented gastroesophageal reflux disease (GERD), patients who underwent a laparoscopic antireflux procedure, in absence of relevant or malignant gastric or duodenal disease, ability to correctly follow the study instructions and procedure cares, and informed consent in writing.

-Exclusion criteria were: Pregnancy, history of allergy to anesthetic drugs, history of esophageal or gastric or duodenal surgery, patients who underwent a laparoscopic antireflux procedure following an achalasia repair, or an antireflux procedure via laparotomy.

The study was approved by the hospital's ethic and research committees. All patients operated on provided their informed consent in writing, including both informed consent for antireflux procedure and the laparoscopic approach one, and they were allowed to voluntarily withdraw from the operation. Their informed consent in writing for each diagnostic test throughout the study (endoscopy studies, $\mathrm{pH}$ monitoring tests, manometries, radiologic studies, and anesthetic evaluation and techniques) were also provided by patients.

Well-documented GERD diagnoses were assessed by means of medical history (age, gender, and risk factors), clinical manifestations (pyrosis, pain, regurgitation or dysphagia), time with symptoms, physical examination, and several diagnostic tests, which included:

-Esophageal radiologic study: Considering pathologic criteria in barium swallow if presence of regurgitation or hiatal hernia (6).

-Upper gastrointestinal endoscopy (with biopsy if any abnormalities are found): Considering pathologic criteria based on Savary-Miller (7) and MUSE (8) esophagitis classifications.

-24 hours esophageal $\mathrm{pH}$ monitoring: Considering pathologic criteria if DeMeester score $>14.72$ points (9).

- Manometry of both esophageal body and the lower esophageal sphincter (LES), considering pathologic criteria if presence of body disorders peristalsis (10) or LES pressure $<11 \mathrm{mmHg}(9)$.

The indication for surgery was centrally based on the patient's symptoms, the duration of the symptoms, and the damage that is present (2). All procedures were per- 
Table I. Demographic and clinical data of the study population

\begin{tabular}{|c|c|c|}
\hline Number of inhabitants, $n$ & 63,055 & \\
\hline Duration of the study, years & 9 & \\
\hline Patients included in the study, $n$ & 100 & \\
\hline Mean age, years \pm SD (range) & $51.31 \pm 13.53(22-83)$ & \\
\hline Gender, male:female, n & $50: 50$ & \\
\hline \multicolumn{3}{|l|}{ Previous history } \\
\hline Chronic bronchitis, $n$ & 11 & \\
\hline Obesity (BMl > 30), n & 10 & \\
\hline Psychiatric disorders, $n$ & 8 & \\
\hline Hypertension, $n$ & 8 & \\
\hline Cardiac failure, $n$ & 6 & \\
\hline \multicolumn{3}{|l|}{ Clinical manifestations, $n(\%)$} \\
\hline Heartburn or pyrosis & 94 & $(40.17)$ \\
\hline Pain episodes & 48 & $(20.51)$ \\
\hline Regurgitation/vomiting & 47 & $(20.09)$ \\
\hline Dysphagia/difficulty swallowing & 29 & $(12.40)$ \\
\hline Mean time with symptoms, months \pm SD (range) & $56.47 \pm 61.33(1-312)$ & \\
\hline Mean time with medication, months \pm SD (range) & $32.32 \pm 36.18(0-240)$ & \\
\hline
\end{tabular}

formed or directly supervised by one of the senior surgeons (GLU, JAF).

Clinical dossiers of every patient were evaluated and registered using the SPSS 12.0 package for Windows (Chicago, Illinois). Data obtained were analysed, performing bi-variate analysis test as appropiate. Differences were considered statistically significant when $p$ value was less or equal than 0.05 .

\section{RESULTS}

One hundred patients from our health care area were detected for this study from December 1997 to February 2007, being diagnosed as having GERD (1), being identified as candidate for a laparoscopic antireflux procedure (5), and having successfully completed the requirements and criteria for this study.

Demographic and clinical data were showed in table I. Alcohol consumption was recorded in 1 case, declaring to drink on a basis daily. Drugs consumption recorded by patients was as follows: calcium antagonists in 4 cases, theophyllines in 4 cases, and beta-blockers in 3 cases.

Regurgitation showed a trend toward being more frequent in obese subjects (body mass index > 30) (7 patients out of 10 obese subjects, 70\%) than in non-obese ones ( 40 out of $90,40 \%, p=0.076$ ). There were no significant association between obesity and other clinical presentations of GERD: pyrosis $(70 \%$ in obese subjects versus (vs.) $96.6 \%$ in non-obese ones respectively, $\mathrm{p}=$ 0.81 ), pain (70 vs. $50 \%$ respectively, $\mathrm{p}=0.11)$; or dysphagia ( $0 \mathrm{vs} .32 .2 \%$ respectively, $\mathrm{p}=0.21)$.
Table II. Diagnostic tests for preoperative GERD assessment

\begin{tabular}{|c|c|c|}
\hline Esophageal radiologic study, n (\%) & 97 & (97) \\
\hline Presence of regurgitation, $\mathrm{n}(\%)$ & 53 & $(54.6)$ \\
\hline Presence of hiatal hernia, $n(\%)$ & 95 & $(97.9)$ \\
\hline Upper gastrointestinal endoscopy, $n$ (\%) & 58 & (58) \\
\hline Normal & 3 & $(5.2)$ \\
\hline Esophagitis | & 11 & $(19)$ \\
\hline Esophagitis \| & 15 & $(25.9)$ \\
\hline Esophagitis III & 14 & $(24.1)$ \\
\hline Esophagitis IV & 4 & (6.9) \\
\hline Stricture & 4 & $(6.9)$ \\
\hline Metaplasia & 7 & $(12.1)$ \\
\hline pH monitoring test, $n(\%)$ & 67 & (67) \\
\hline DeMeester score > 14.72 points, $n(\%)$ & 52 & $(77.6)$ \\
\hline Mean DeMeester score, points \pm SD (range) & $44.52 \pm 35.09$ & $(1-192)$ \\
\hline Manometry, $n(\%)$ & 81 & (81) \\
\hline Body disorders peristalsis, $n(\%)$ & 38 & $(46.9)$ \\
\hline LES pressure $<11 \mathrm{mmHg}, \mathrm{n}(\%)$ & 16 & $(19.8)$ \\
\hline Mean LES pressure, $\mathrm{mmHg} \pm \mathrm{SD}$ (range) & $8.43 \pm 4.70$ & $(2-25)$ \\
\hline
\end{tabular}

GERD: Gastroesophageal reflux disease; LES: Lower esophageal sphincter; $n$ : Number of patients with test performed; SD: Standard deviation.

Table III. Patients without esophageal radiologic study or resulting in normal

\begin{tabular}{lccccc}
\hline X-ray & Endoscopy & pH-m & Mano & $\begin{array}{c}\text { Treatment } \\
\text { months \& kind }\end{array}$ & S-indication \\
\hline$(-)$ & V, stenose & $(-)$ & $N$ & 1, omeprazole & Noncompliance \\
$(-)$ & $\mathrm{N}$ & $\mathrm{A}$ & $\mathrm{A}$ & $\begin{array}{l}\text { 48, omeprazole } \\
\text { Complication }\end{array}$ \\
$(-)$ & $(-)$ & $\mathrm{N}$ & $\mathrm{N}$ & 24 , lansoprazole & Noncompliance \\
$\mathrm{N}$ & $\mathrm{N}$ & $\mathrm{A}$ & $\mathrm{A}$ & 36, pantoprazole & Persistence \\
$\mathrm{N}$ & $\mathrm{N}$ & $\mathrm{N}$ & $\mathrm{A}$ & 1 , antiacids & Noncompliance \\
\hline (-): Test was not performed; A: Abnormality; Complication: Complications of the \\
disease; Mano: Manometry; N: Normal; Noncompliance: Noncompliance of the \\
patient with medical treatment; Persistency: Persistent or recurrent esophagitis in \\
spite of currently optimal medical treatment; pH-m: pH monitoring test; X-ray: \\
Esophageal radiologic study; S-indication: Indication for surgical approach.
\end{tabular}

Eighteen subjects aged over 65 years (yr). Comparing clinical presentation of 18 subjects aged over $65 \mathrm{yr}$, with subjects younger than this age, no differences were observed (pyrosis [100\% in elderly subjects versus $94 \%$ in younger subjects, NS], pain [27.8 vs. 52.4\%, NS], regurgitation [33.3 $v s .26 .8 \%, \mathrm{NS}]$, dysphagia [27.8 vs. $29.3 \%, \mathrm{NS}]$ ).

The medication was recorded by the subjects in all cases. Among them, 6 were taking antiacids, 82 were under proton pump inhibitor (PPI), 3 were taking prokinetics, and 2 were consumpting $\mathrm{H}_{2}$-receptor antagonist.

Patients did not homogeneously perform the preoperative diagnostic protocol (Table II). Patients without esophageal radiologic study or resulting in normal are presented in table III.

Endoscopy was not performed in 42 cases.

Thirteen subjects refused to perform both endoscopy and functional tests. 
In manometry, an absence of motility in esophageal body was detected in 8 subjects, and the rest of manometric abnormalities in esophageal body were classified as non-specific disorders.

Nissen fundoplication was performed in 92 cases, and Toupet fundoplication was performed in 8 patients. The indications for surgery were: Noncompliance of the patient with ongoing effective medical treatment (including refusal, preference, reduced quality of life, drug-dependency, and drug side-effects) in 30 cases, persistent or recurrent esophagitis in spite of currently optimal medical treatment and in association with symptoms in 52 cases, and complications of the disease (stenoses, ulcers, and Barret's esophagus) in 12 cases. On this issue, no data were retrospectively found in 6 patients.

Fifty-five endoscopic studies out of 58 performed showed pathologic findings. Indications for surgery were assessed: By noncompliance of the patient in 13 out of 55 patients, by persistent or recurrent esophagitis in spite of treatment in 30 cases out of 55 cases, and by complication observed in endoscopy in 12 cases left.

Every patient with normal endoscopy showed hiatal hernia in barium swallow: Among them, in 2 cases out of 3 a pathologic DeMeester score (> 14.71 points) and no findings in manometric test were showed, and their indication for surgery were assessed based on recurrence of symptoms in spite of currently optimal medical treatment. The third subject without endoscopic findings refused to perform $\mathrm{pH}$ monitoring test, and indication was assessed based on the persistence of symptoms after 12 months under omeprazole.

The indication for sugery in 13 patients who refused to complete endoscopic, $\mathrm{pH}$ monitoring, and manometric preoperative studies was established based on: a) recurrence of symptoms after having stopped medication for 68 \pm 284.26 months in 6 cases; b) based on noncompliance of the patient for $7.40 \pm 22.63$ months $(\mathrm{p}=0.85)$ in 5 cases; and c) no data were retrospectively found in 2 cases.

Comparing preoperative diagnostic tests in elderly patients to younger subjects, no differences were observed in esophageal radiologic disorders found $(94.4 \%$ in elderly subjects $v s .95 .1 \%$ in younger subjects; $\mathrm{p}=0.31$ ), in endoscopic disorders (55.6 vs. 54.9\% respectively, $\mathrm{p}=0.27$ ), in $\mathrm{pH}$-monitoring disorders (55.6 vs. 51.2\%, $\mathrm{p}=0.25)$, nor in manometric disorders (33.3 vs. $22.0 \%, \mathrm{p}=0.24)$.

\section{DISCUSSION}

Today, gastroesophageal reflux disease (GERD) is defined as the presence of a risk for organic complications by increased gastroesophageal reflux and/or a significant limitation of health-related well-being such as quality of life due to reflux symptoms (1). Data from literature indicate that up to $44 \%$ of the adult population describe symptoms characteristic of GERD, and 10-50\% will need long-term treatment of some kind for them (2). Despite there are several issues about GERD that remains uncertain, as indication for surgery (11), the American College of Gastroenterology recommended in 2005 (5) that antireflux surgery performed by an experienced surgeon is a maintenance option for the patient with well-documented gastroesophageal reflux disease (level of evidence: II). In order to examine our patients' profile, the preoperative workup, and their indication for surgical treatment in GERD, we retrospectively studied patients who underwent a laparoscopic antireflux procedure.

Recently, Ponce and the Iberge Study Group (3) have reported a prevalence of GERD among adults of $15 \%$ in Spain, which merely showed some detriment from $32 \%$ reported previously (4). Our GERD patient's profile resulted to be transferable to the profile described in the Spanish meta-analysis published in 2006 (3). The average age of our subjects were 3.2 years older than the average age of Spanish population, but both of them showed an overlap between their confidence intervals, despite the fact that our study was not designed as an epidemiological work, and then, results among both studies are not comparable.

Obesity has been shown to be a significant predisposing factor for GERD, and could be a contraindication to antireflux surgery. Some authors have already demonstrated that clinical outcome did not differ among patients stratified by preoperative body mass index (BMI) (12). Following that evidence obese subjects were not excluded from the study. Despite obesity has been associated with heartburn in the Spanish meta-analysis (3), our subjects did not show any association among this condition and any clinical presentation, on the contrary that others authors have reported $(3,13)$. The sample of the subjects included in this study was homogeneous based on both the indication for surgery in every patient, and the severity of their diseases $(1,2)$. When comparing obese subjects and non-obese subjects, no significant differences were expected between their profiles, so it was. Nevertheless, a trend toward an association among obesity and regurgitation was observed in our subjects. It seems that the limited number of subjects studied could have avoided to find that association also.

GERD is a multifactorial disease in which the gastroesophageal junction with its special anatomical and functional components is important (1). Patients did not homogeneously perform the preoperative diagnostics tests protocol. Most of patients did perform morphologic tests such esophageal radiographic study. Among them, almost all did show the presence of a hiatal hernia, despite reflux of barium during radiographic evaluation has been reported positive in $25-75 \%$ of symptomatic patients (14). Moreover, endoscopy was performed in two thirds patients, in which almost all did show an erosive reflux disease with esophagitis.

Based on these findings, anatomical disorders were demonstrated in most of patients to be operated on. Never- 
theless, one patient showing normal morphological tests and DeMeester score in $\mathrm{pH}$-monitoring test, and an hypotonic lower esophageal sphincter (LES) was found in our study. Moreover, one subject who refused to perform both morphological tests that presented normal functional tests was also detected. In both subjects surgical approach was assessed based on the presence of symptoms characteristic of GERD, added to the noncompliance of the patient to follow medical treatment (including refusal, preference, reduced quality of life, drug-dependency, and drug side-effects), as recommended by authors $(1,2)$.

Functional studies were performed if no morphologic evidence could be found also $(1,9)$. These fuctional studies included esophageal manometry, in which LES pressure was altered in a few cases only. It has been suggested that patients who have ineffective peristalsis may need to avoid surgery (15). In our subjects Toupet fundoplication procedure was performed if manometry revealed an absence of esophageal motility $(1,2)$. So, manometry resulted to be more useful to decide surgical technique than to determine the pathophysiologic cause of GERD in our preoperative workup; nevertheless, manometry must also assess the location of the $\mathrm{pH}$ electrode in relation to the LES (2).

These functional studies also included the $24 \mathrm{hr}$ esophageal $\mathrm{pH}$-monitoring test, which is considered to be the gold standard investigation to assess the diagnostic of GERD in absence of morphological disorders, and it is recommended to be included in patient's preoperative workup (1). In our patients, pathologic DeMeester score was observed in three quarters of cases, due to the fact patients with hiatal hernias or reflux barium at fluoroscopy have been reported to have more acid exposure by ambulatory $\mathrm{pH}$ test (16).

Based on this diagnostic test ranking order for GERD, our subjects were diagnosed as well-documented GERD (both nonerosive reflux disease and both erosive reflux disease) in $100 \%$ of cases.

More severe clinical presentation, a higher incidence of esophagitis and metaplasia, a greater DeMeester score, and higher changes in motility have been described in the elderly $(13,17)$ although it is not clear which factors lead to a more severe GERD in these patients. In this study, no significant differences were observed in the number of the symptoms recorded by subjects aged greater than or equal to 65 years compared to younger ones. Moreover, in older patients preoperative diagnostic tests showed that there were no significant differences in the incidence of the parameters related to complicated GERD also. So this hypothesis could not be demonstrated in this serie. Some authors have only involved economic factors with respect to the break-point between medical and surgical treatment (18).

Concerning the indication for surgery, the distribution was similar to those described in literature $(1,2)$, and therefore mainly symptoms and their relation to ongoing medical treatment played the major role on it. In our subjects, mean time with symptoms and mean time with medication seemed to be so long. This fact could be explained because half the patients could have remained without interference with daily activities for long time in absence of erosive esophagitis, in addition to most of patients did take adequate medical treatment with proton pump inhibitor (PPI) (19). Despite our patients seemed to have waited for so long, the neccesity of long-term treatment with PPI is the basis for establishing an indication for antireflux surgery (20). So, this criterion has been followed in all patients throughout the study.

Subjects included in this study have been under PPI for so long (19), half of them have presented reflux esophagitis or complicactions (1), and half of them have showed an abnormal DeMeester score in pH-monitoring test. Indications for surgery consisted of significant limitation of health-related well-being such as quality of life (in 30 cases), persistent or recurrent esophagitis in spite of treatment in 52 cases, and complications of the disease (stenoses, ulcers, and Barret's esophagus) in 12 cases. Based on these results, our patients may be considered as patients with severe GERD $(1,2)$.

Data analysed retrospectively revealed that most of patients could be classified as severe GERD, based on the facts that most of them have been under PPI for so long (19); and despite that, the severity of their symptoms, their recurrence or persistence, or the mucosal damage that was present did make them to be candidates for surgery $(1,2)$.

Finally, we can conclude that: a) Based on this diagnostic test ranking order for GERD, $100 \%$ of subjects were well-documented and diagnosed as GERD (both nonerosive reflux disease and both erosive reflux disease), and their indication for laparoscopic treatment were retrospectively assessed in $94 \%$ of cases; b) obesity or age did not represent a contraindication for antireflux surgery; and c) the neccesity of long-term treatment with PPI was the basis for establishing an indication for antireflux surgery.

\section{ACKNOWLEGMENTS}

This work has been awared with first position in medical category in Eight Research Awards in our Health Care Area, SESPA, Asturias, Spain

\section{REFERENCES}

1. Fuchs K-H, Eypasch E. Gastroesophageal reflux disease -Update 2006. In: Neugebauer EAM, Sauerland S, Fingerhuf A, Millat B, Buess G, editors. The EAES Guidelines for endoscopic surgery. Heidelberg: Springer; 2006. p. 125-42.

2. Eypasch E, Neugebauer EAM, Fisher F, Troidl H, Blum AL, Collet $\mathrm{D}$, et al. The EAES Clinical Practice Guidelines on laparoscopic antireflux surgery for gastroesophageal reflux disease (1997). In: Neugebauer EAM, Sauerland S, Fingerhuf A, Millat B, Buess G, editors. The EAES Guidelines for endoscopic surgery. Heidelberg: Springer; 2006. p. 97-124. 
3. Ponce O, Vegazo O, Beltrán B, Jiménez J, Zapardiel J, Calle D, et al. Prevalence of gastro-oesophageal reflux disease in Spain and associated factors. Aliment Pharmacol Ther 2006; 23: 175-84.

4. Díaz-Rubio M, Moreno-Eola-Olaso C, Rey E, Locke GR III. Symptoms of gastro-oesophageal reflux: prevalence, severity, duration and associated factors in a Spanish population. Aliment Pharmacol Ther 2004; 19: 95-105.

5. DeVault KR, Castell DO. Updated guidelines for the diagnosis and treatment of gastroesophageal reflux disease. Am J Gastroenterol 2005; 100: 190-200.

6. Gelfand DW. Radiologic evaluation of the farinx and esophagus. In: Gelfand DW, Richter JE, editors. Dysphagia: Diagnosis and treatment. New York: Ikaqu-Shoiq; 1988. p. 45-83.

7. Savary M, Miller G. The esophagus. In: Fassman AG, editor. Handbook and atlas of endoscopy. Switzerland: Solothertn; 1978. p. 135.

8. Armstrong D, Blum AL, Savary M. Reflux disease and Barrett's esophagus. Endoscopy 1992; 24: 9-17.

9. DeMeester TR, Johnson LS, Joseph GJ, Toscano MS, Hall AW, Skinner DB. Patters of gastroesophageal reflux in health and disease. Ann Surg 1976; 184: 459-70.

10. Eypasch EP, Stein H, DeMeester TR, Johansson KE, Barlow AP, Schneider GT. A new technique to define and clarify esophageal motor disorders. Am J Surg 1990; 159: 144.

11. Trullenque Juan R, Torres Sánchez T, Martí Martínez E, Martínez Abad M, Trullenque Perís R, Delgado Gomis F. Surgery for gastroesophageal reflux disease: A comparative study between the open and laparoscopic approaches. Rev Esp Enferm Dig 2005; 97: 328-37.

12. D'Alessio MJ, Arnaoutakis D, Giarelli N, Villadolid DV, Rosemurgy AS. Obesity is not a contraindication to laparoscopic Nissen fundoplication. J Gastrointest Surg 2005; 9 (7): 949-54.
13. Richter JE. Gastroesophageal reflux disease in the older patient: Presentation, treatment, and complications. Am J Gastroenterol 2000; 95 (2): 368-73.

14. Sellan RJ, DeCaestecker JS, Heading RC. Barium radiology: A sensitive test for gastroesophageal reflux. Clin Radiol 1987; 38 : 303-7.

15. Kauer WK, Peters JH, DeMeester TR, Heimbucher J, Ireland AP, Bremner CG. A tailored approach to anti-reflux therapy. J Thorac Cardiovasc Surg 1995; 110: 141-6.

16. Johnston BT, Troshinsky MB, Castell JA, Castell DO. Comparison of barium radiology with esophageal $\mathrm{pH}$ monitoring in the diagnosis of gastroesophageal reflux disease. Am J Gastroenterol 1996; 91: 1181-5

17. Pizza F, Rossetti G, Limongelli P, Del Genio G, Maffettone V, Napolitano $\mathrm{V}$, et al. Influence of age on outcome of total laparoscopic fundoplication for gastroesophageal reflux disease. World J Gastroenterol 2007; 13 (5): 740-7.

18. Boom VDG, Go PMMYH, Hameeteman W, Dallemagne B. Costeffectiveness of medical versus surgical treatment in patients with severe or refractory gastroesophageal reflux in The Netherlands. Scand J Gastroenterol 1996; 31: 1-9.

19. Castro Fernández M, García Díaz E, Larraona JL, Rodríguez Hornillo MC, Lamas Rojas E, Núñez Hospital D, et al. Efficacy of lowdose lansoprazole in the treatment of non-erosive gastroesophageal reflux disease: Influence of infection by Helicobacter pylori. Rev Esp Enferm Dig 2006; 98 (3): 170-9.

20. Klinkenberg-Knol EC, Nelis F, Dent J, Snel P, Mitchell B, Princhard $\mathrm{P}$, et al. Long-term omeprazole treatment in resistant gastroesophageal reflux disease: Efficacy, safety, and influence on gastric mucosa. Gastroenterology 2000; 118: 661-9. 